\title{
The role of serum 25-hydroxyvitamin $D$, ionized calcium and phosphorus in breast cancer females: A case-control study
}

\author{
Nadia Ahmed Abd El Moneim ${ }^{1}$, Taha Ismail Mahmoud Hewala * ${ }^{2}$, Mona Rashad ${ }^{3}$, \\ Yousria El-Sayed ${ }^{4}$, Nehal Abu-Samra ${ }^{5}$, Medhat Anwar ${ }^{6}$ \\ ${ }^{I}$ Department of Cancer Management and Research \\ ${ }^{2}$ Department of Radiation sciences \\ ${ }^{3}$ Department of Applied Medical Chemistry \\ ${ }^{4}$ Department of Human Physiology \\ ${ }^{5}$ Department of Basic Sciences, Faculty pf Physical Therapy, Pharos University in Alexandria \\ ${ }^{6}$ Department of Experimental and Clinical Surgery, Medical Research Institute, Alexandria University, Egypt \\ *Corresponding author E-mail: tahahewala@hotmail.com
}

Copyright $(92015$ Nadia Ahmed Abd El Moneim et al. This is an open access article distributed under the Creative Commons Attribution License, which permits unrestricted use, distribution, and reproduction in any medium, provided the original work is properly cited.

\begin{abstract}
Aim: To evaluate the diagnostic and prognostic value of serum 25- hydroxyvitamin $\mathrm{D}(25(\mathrm{OH}) \mathrm{D})$, ionized calcium and phosphorus in comparison with serum CA15.3 as the most commonly used breast cancer marker.

Participants and methods: This study was conducted on 45 breast cancer female patients with recently detected breast cancer before surgery and 45 apparently healthy female controls of matched age, menstrual and socioeconomic status as breast cancer patients group. Serum $25(\mathrm{OH}) \mathrm{D}$, ionized calcium, phosphorus and CA15.3 were measured using readyfor-use commercially available kits.

Results: Serum levels of $25(\mathrm{OH}) \mathrm{D}$ and ionized calcium in the breast cancer patients group were significantly lower than those of the control group, while serum levels of phosphorus and CA15.3 in breast cancer patients group were significantly higher than those of the control group. The area under the ROC curve for serum ionized calcium (81.7\%) was significantly greater than that of $25(\mathrm{OH}) \mathrm{D}(75.3 \%)$, CA $15.3(70.1 \%)$ and phosphorus $(62.8 \%)$. The odd's ratio of vitamin D was 0.0937 (95\% CI=0.0311-0.2823), of ionized calcium was 0.0464 (95\% CI=0.015-0.141) and of phosphorus was $2.6801(95 \% \mathrm{CI}=1.1269-6.3742)$ in breast cancer patients group. Serum phosphorus was significantly correlated with age and menopausal status of breast cancer patients.

Conclusion: Our results suggest that serum ionized calcium and 25(OH) D were superior to serum CA15.3 and phosphorus for prediction of breast cancer. In addition, our results indicate that $25(\mathrm{OH}) \mathrm{D}$ and calcium may decrease the risk for breast cancer incidence, while phosphorus may increase this risk. None of the assayed biomarkers has a prognostic role in breast cancer.
\end{abstract}

Keywords: Breast Cancer; Incidence; Diagnosis; Prognosis; 25-Hydroxyvitamin D; Ionized Calcium; Phosphorus; CA15.3.

\section{Introduction}

Breast cancer is the most common cancer among women in Arab countries [1]. In Egypt, breast cancer is the most common cancer among women, representing $18.9 \%$ of total cancer cases with an incidence rate of 49.6 per 100000 population [2].

Dietary patterns are suggested to be an important environmental risk factor for cancer. Inorganic phosphate $(\mathrm{Pi})$ is a dietary constituent well-known for its role in skeletal mineralization, and normal levels of Pi are essential to maintain normal cellular function [3]. Elevated levels of serum Pi were found to modify gene expression as well as protein translation and affect the rate of cell proliferation in vitro [4], [5]. Moreover, a high Pi in a diet has been reported to result in a significantly increased development of lung and skin cancers, as well as perturbed normal brain growth in animal studies [6], [7], which denoted the potential link between Pi and carcinogenesis in humans. In the human body, 
$\mathrm{Pi}$ is known to be mainly regulated by a set of hormonal and metabolic factors, which tightly control calcium homeostasis, i.e. vitamin D and parathyroid hormone (PTH), and a recently identified Pi-regulating hormone, fibroblast growth factor 23 (FGF-23).

Although vitamin D deficiency is known mainly for its association with fractures and bone disease, [8] its newly recognized association with risk of several types of cancer is receiving considerable attention [9]. The high prevalence of vitamin D deficiency, combined with the discovery of increased risks of certain types of cancer in those who are deficient, suggest that vitamin D deficiency may account for several thousand premature deaths from much cancer annually [10] including breast cancer [11]. This discovery creates a new impetus for ensuring adequate vitamin D intake in order to reduce the risk of cancer. A low serum level of $25(\mathrm{OH}) \mathrm{D}$, the principal form of circulating vitamin $\mathrm{D}$, is the main marker of vitamin D deficiency [12].

Several studies have shown that calcitriol $(1,25(\mathrm{OH}) 2 \mathrm{D} 3)$ inhibits the growth of human breast cancer cell lines, induces differentiation and apoptosis in breast cancer cells, inhibits invasion and metastasis, has an anti-inflammatory effect, inhibits estrogen synthesis and signaling and suppresses aromatase expression directly or indirectly through inhibition of prostaglandins synthesis and expression [13].

It has been argued that free (ionized) calcium provides the best indication of calcium status because it is biologically active and tightly regulated by calcium-regulating hormones [14]. Calcium signals induced by the $\mathrm{Ca}^{2+}$ regulatory hormone 1, 25-dihydroxyvitamin D3 $(1,25(\mathrm{OH}) 2 \mathrm{D} 3)$ are critical in determining the fate of cancer cells. Elevated extracellular levels of calcium in experimental models increase cell differentiation, decrease proliferation, induce apoptosis and down-modulate invasion; all of which would have tumor protective effects [15].

Cancer antigen 15-3 (CA15-3) is a circulating breast cancer-associated antigen. CA15-3 has low sensitivity in the diagnosis of early stages of breast cancer [16]. However, it can be used for monitoring the response of breast cancer patients to therapy and in detecting recurrent disease [17].

The aim of this study was to compare the diagnostic and prognostic values of serum 25-hydroxyvitamin $\mathrm{D}(25(\mathrm{OH}) \mathrm{D})$, ionized calcium and phosphorus with those of serum CA15.3 as the most commonly used breast cancer marker.

\section{Participants and methods}

Ninety females were enrolled in this case-control study. Females were divided into two groups: Group I (breast cancer patients group): It included 45 female patients with breast invasive ductal carcinoma of clinical stages II and III [18] (recently detected, having not undergone surgery or receiving chemotherapy). Their mean age was (43.73 \pm 12.2$)$ years. Group II (control group): included 45apparently healthy female volunteers of comparable age $(42.18 \pm 11.05)$, menstrual cycle and socioeconomic status. Patients and controls were recruited from the Departments of Experimental and Clinical Surgery and Cancer Management \& Research of the Medical Research Institute, Alexandria University in the period from January 2010 to May 2011.

This research protocol was approved by the ethical committee of Medical Research Institute. Both groups were asked to sign an informed consent form indicating their acceptance to participate in the study. Each patient underwent full history recording, through clinical examination, routine laboratory investigations, including complete blood count (CBC), mammography of breast and ultrasonography of abdomen and liver, radiological investigations, including X-ray chest, CT scan and bone scan when needed and fine needle aspiration cytology (FNAC) of breast mass to establish the pathological diagnosis in the patients.

The clinicopathological data were obtained from patients' pathological reports by the oncologist. The collected data included tumor size, tumor pathological grade, axillary lymph node involvement, vascular invasion, Her-2 expression and status of estrogen receptor (ER) and progesterone receptor (PR). Each breast cancer patient's clinical stage was determined by the oncologist according to the tumor-nodes-metastasis (TNM) classification system [18].

All 45 breast cancer patients underwent Modified Radical Mastectomy (MRM) surgery [19], and then received adjuvant combination chemotherapy [5-Fluorouracil, Adriamycin and Cyclophosphamide (FAC)] [20] for six cycles. After 6 cycles of chemotherapy, breast cancer patients were evaluated clinically, laboratory and radiologically to estimate the clinical response. The patients were followed up clinically for 24 months for observation of local recurrence or metastasis.

\subsection{Laboratory investigations}

Blood samples were collected once from the control group and from breast cancer group before surgery. Immediately after withdrawing, blood samples were allowed to coagulate and centrifuged for 20 minutes at 3500rpm. The separated serum samples were aliquoted, frozen at $-80{ }^{\circ} \mathrm{C}$, and stored until assayed. After thawing, each serum aliquot was assayed only once. Determination of serum levels of 25- hyroxyvitamin D and CA 15-3 were carried out at Radiation Science Department, Medical Research Institute, Alexandria University. Serum ionized calcium and phosphorus levels were assayed at Human Physiology Department, Medical Research Institute, Alexandria University. 


\subsubsection{Determination of serum 25-hydroxyvitamin D levels}

For quantification of serum 25-hydroxyvitamin D levels, a ready-for-use radioimmunoassay (RIA) kit (DIAsource, Belgium) was used according to the manufacturer's protocol. At first, calibrators, quality controls and serum samples were extracted with acetonitrile. A fixed amount of ${ }^{125}$ I-labeled 25 -hydroxyvitamin D competes with the 25 hydroxyvitamin D from treated serum samples, controls or calibrators, for binding to a fixed amount of specific monoclonal antibody sites immobilized to the lower and inner surface of plastic tubes. After 2-hrs incubation at room temperature on a tube shaker, an aspiration step terminates the competition reaction. The tubes were then washed with 2 $\mathrm{ml}$ washing solution and counted for 60 seconds in a gamma counter (Perkin Elmer, Finland).

\subsubsection{Determination of serum ionized calcium levels}

Serum levels of ionized calcium were measured using ion selective electrode method (Roche AVL 9180, Austria). Membrane potentials are caused by the permeability of certain types of membranes to selected anions or cations. Such membranes are used to fabricate ion selective electrodes that selectively interact with a single ionic species. The potential produced at the membrane-sample solution interface is proportional to the logarithm of the ionic activity or concentration of the ion in question [21].

\subsubsection{Determination of serum phosphorus levels}

Serum levels of phosphorus were measured using a ready-for-use colorimetric method (Human, Germany) according to the manufacturer's protocol. Phosphate reacts with molybdate in strong acidic medium to form a complex. The absorbance of this complex at $340 \mathrm{~nm}$ is directly proportional to the phosphate concentration.

\subsubsection{Determination of serum CA15-3 levels}

The levels of serum CA 15-3 were determined using a ready-for-use Immunoradiometric assay (IRMA) kit (Diasource, Belgium) according to the producer's protocol. Briefly, serum was added to a plastic tube coated with the capture antibody (Mab1) and shaken for 90 minutes at room temperature. After washing, ${ }^{125}$ I-labeled anti-CA 15-3 antibody (Mab2) was added and the reaction tubes were shaken for 90 minutes at room temperature. After washing, the bound radioactivity in each tube was counted for 60 seconds in a gamma counter (Perkin Elmer, Finland). Computer-assisted data reduction was used to simplify the calculations. The 5-parameter logistic function curve was used to calculate CA 15-3 level in each serum sample.

\section{Statistical analysis}

Statistical analysis was performed using SPSS 11.5 software package. The data were abnormally distributed, so nonparametric tests were used. The Non-parametric Mann-Whitney U-test was used for studying differences between breast cancer patients group and controls group regarding serum $25(\mathrm{OH}) \mathrm{D}$, ionized calcium, phosphorus and CA15.3. The Non-parametric Spearman's test was used to investigate correlations between serum biomarkers concentrations and the patients' clinicopathological data. The diagnostic values of serum $25(\mathrm{OH}) \mathrm{D}$, ionized calcium, phosphorus and CA15.3 were compared using the Receiver Operating Characteristic (ROC) curve analysis. To obtain the optimal cutoff point for each parameter in predicting breast cancer, we chose the point on the ROC curve which represented the largest sum of sensitivity and specificity, [22] or equivalently, the Youden value. Association of studied serum biomarkers with the risk of breast cancer occurrence was studied using the odd's ratio test. Univariate survival analysis of the studied parameters was assessed using the kaplan-Meyer method. Statistical differences between survival curves were evaluated using the log-rank test. $\mathrm{P}$ values $<0.05$ were accepted as significant.

\section{Results}

\subsection{Serum levels of 25- hydroxyvitaminD, ionized calcium, phosphorus and CA15.3 in breast cancer patients and controls}

The mean \pm SE levels of serum 25- hydroxyvitaminD, ionized calcium, phosphorus and CA15.3 in apparently normal control subjects and breast cancer patients group were shown in table (1). The statistical analysis of these results revealed that the levels of serum vitamin $\mathrm{D}$ and ionized calcium of breast cancer patients were significantly lower than those of apparently normal healthy controls, while the levels of serum phosphorus and CA15.3 of breast cancer patients were significantly higher than those of the apparently normal healthy control. 
Table 1: The levels of serum 25-Hydroxyvitamin D, ionized calcium, phosphorus and CA15.3 in the controls and breast cancer patients before surgery

\begin{tabular}{|c|c|c|c|}
\hline \multirow[b]{2}{*}{ Serum biomarker } & \multicolumn{2}{|c|}{ Mean $\pm \mathrm{SE}$} & \multirow[b]{2}{*}{ P-value } \\
\hline & $\begin{array}{l}\text { Controls group } \\
\qquad(n=45)\end{array}$ & $\begin{array}{l}\text { Breast cancer } \\
\text { patients group } \\
\quad(n=45)\end{array}$ & \\
\hline 25- hydroxyvitamin D (ng/dl) & $165.2 \pm 41.37$ & $49.81 \pm 2.42$ & $0.00^{*}$ \\
\hline Ionized calcium(mg/dl) & $5 \pm 0.03$ & $4.85 \pm 0.11$ & $0.00 *$ \\
\hline Phosphorus (mg/dl) & $3.64 \pm 0.14$ & $3.86 \pm 0.11$ & $0.039 *$ \\
\hline CA15.3 (U/ml) & $13.84 \pm 0.78$ & $21.66 \pm 2.14$ & $0.001 *$ \\
\hline
\end{tabular}

SE: standard error n: sample size

*: significance was considered at p-value $<0.05$

4.2. Comparing the values of serum 25-hydroxyvitamin D, ionized calcium, phosphorus and CA15.3 as diagnostic markers in breast cancer patients using the receiver operating characteristic (ROC) curve analysis.

As shown in table (2) and figures 1 and 2, the ROC curve analysis was used in the present study to compare the diagnostic values of serum 25-hydroxyvitamin $\mathrm{D}$, ionized calcium, phosphorus, and CA15.3 depending on the area under the ROC curve (AUC).The The higher AUC corresponds to a better diagnostic test. Serum ionized calcium showed a significant AUC (81.7\%), ( $\mathrm{p}=0.00)$, with sensitivity $(72.7 \%)$ and specificity $(84.1 \%)$ at a cut-off value $(4.85$ $\mathrm{mg} / \mathrm{dl})$. Serum 25-hydroxyvitamin D showed a significant AUC (75.3\%), $(\mathrm{p}=0.00)$, with sensitivity $(56.8 \%)$ and specificity $(88.6 \%)$ at a cut-off value $(66.73 \mathrm{ng} / \mathrm{dl})$. Serum CA15.3 showed a significant AUC $(70.1 \%),(\mathrm{p}=0.001)$, with sensitivity (36.4\%), and specificity $(88 \%)$ at a cut-off value $(21.46 \mathrm{U} / \mathrm{ml})$. Serum phosphorus showed a significant AUC $(62.8 \%),(\mathrm{p}=0.04)$, with sensitivity $(61.4 \%)$ and specificity $(62.8 \%)$ at a cut-off value $(3.65 \mathrm{mg} / \mathrm{dl})$.

Table 2: The ROC curve-based characteristics for serum 25- hydroxyvitamin D, ionized calcium, phosphorus and CA15.3.

\begin{tabular}{llllll}
\hline \multicolumn{1}{c}{ Serum biomarker } & AUC \% & p-value & Cut off-value & Sensitivity $\%$ & Specificity \% \\
\hline Ionized calcium (mg/dl) & 81.7 & $0.00^{*}$ & 4.85 & 72.7 & 84.10 \\
25- hydroxyvitamin D (ng/dl) & 75.3 & $0.00^{*}$ & 66.73 & 56.8 & 88.6 \\
CA15.3 (U/ml) & 70.1 & $0.001^{*}$ & 21.46 & 36.4 & 88 \\
Phosphorus (mg/dl) & 62.8 & $0.04^{*}$ & 3.65 & 61.4 & 62.8 \\
\hline
\end{tabular}

AUC: Area under the ROC curve

*Significance was considered at $\mathrm{p}$-value $<0.05$.

\subsection{The correlations between serum 25 -hydroxyvitamin D, ionized calcium, phosphorus and CA15.3 in breast cancer patients before surgery.}

All of the correlations between the assayed serum biomarkers were non-significant.

\subsection{Correlations of serum 25-hydroxyvitamin D, ionized calcium, phosphorus and CA15.3 with clinicopathological data of breast cancer patients before surgery}

Serum phosphorus showed significant direct correlations with age and menopausal status $(r=0.430, p=0.004 \& r=0.341$, $\mathrm{p}=0.024$; respectively) as shown in figures 3 and 4 . The other correlations were non-significant $(\mathrm{p}>0.05)$.

\subsection{The association of serum 25 -hydroxyvitamin $D$, ionized calcium and phosphorus with the risk of breast cancer incidence}

The values of odd's ratios and confidence intervals at certain cut-off values for serum 25-hydroxyvitamin D, ionized calcium and phosphorus were shown in table (3). 


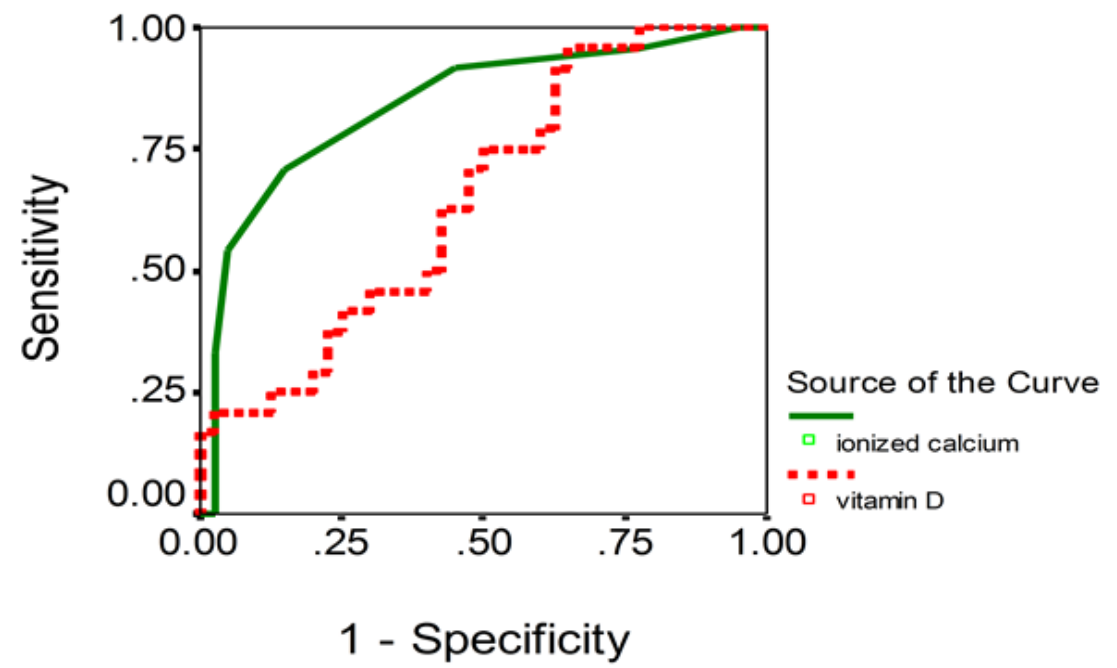

Fig. 1: Graphical representation for the ROC curves for serum 25-hydroxyvitamin D and ionized calcium.

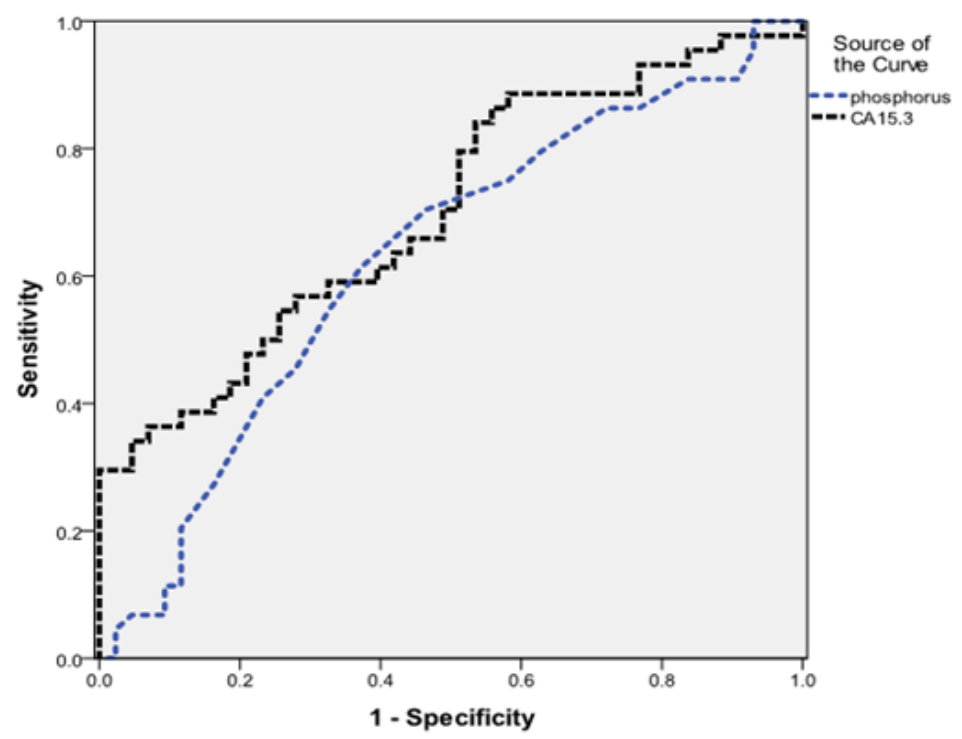

Fig. 2: Graphical representation for the ROC curves for serum phosphorus and CA15.3.

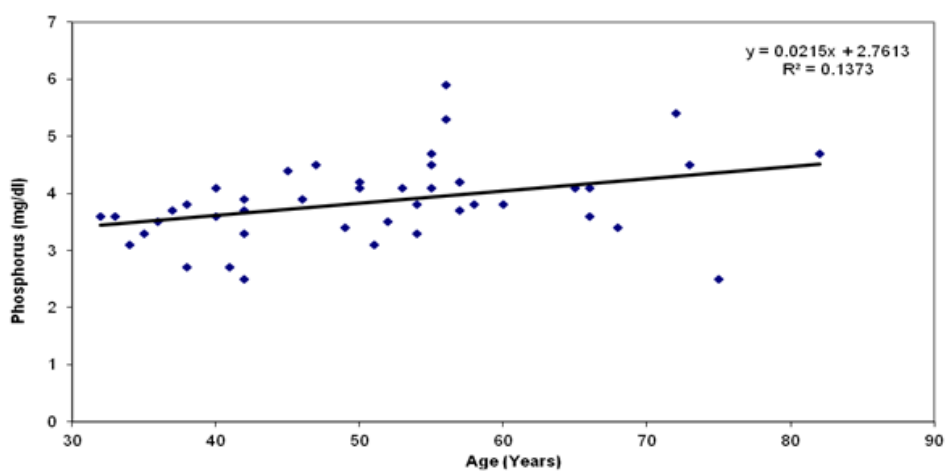

Fig. 3: The correlation between age and serum phosphorus levels in breast cancer patients before surgery. 


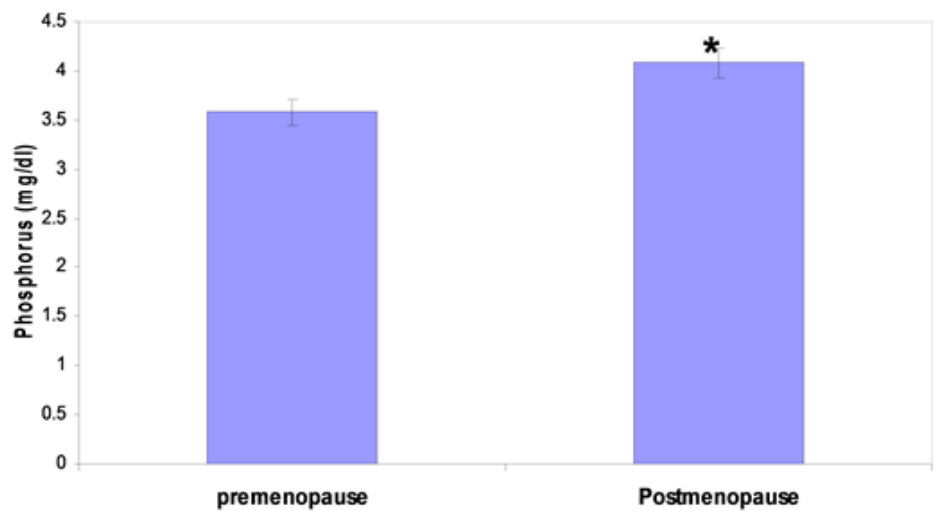

Fig. 4: Mean \pm SE of serum phosphorus levels in premenopausal and postmenopausal breast cancer patients.

*: significance was compared with premenopausal breast cancer patients.

Significance was considered at $\mathrm{p}$-value $<0.05$

Table 3: The association of serum 25-hydroxyvitamin $\mathrm{D}$, ionized calcium and phosphorus with the risk of breast cancer incidence.

\begin{tabular}{|c|c|c|c|c|c|c|}
\hline \multirow[b]{2}{*}{ cut-off } & \multicolumn{2}{|c|}{ Phosphorus (mg/dl) } & \multicolumn{2}{|c|}{ Ionized calcium (mg/dl) } & \multicolumn{2}{|c|}{ Vitamin D (ng/dl) } \\
\hline & $>3.65$ & $\leq 3.65$ & $>4.85$ & $\leq 4.85$ & $<66.73$ & $\geq 66.73$ \\
\hline Breast cancer group & 28 & 17 & 6 & 39 & 40 & 5 \\
\hline Apparently normal control group & 16 & 29 & 35 & 10 & 19 & 26 \\
\hline Odd's ratio $(\mathrm{OR})$ & \multicolumn{2}{|c|}{2.6801} & \multicolumn{2}{|r|}{0.0464} & \multicolumn{2}{|c|}{0.0937} \\
\hline $95 \% \mathrm{CI}$ & \multicolumn{2}{|c|}{$1.1269-6.3742$} & \multicolumn{2}{|r|}{$0.015-0.141$} & \multicolumn{2}{|c|}{$0.0311-0.2823$} \\
\hline $\mathrm{p}$-value & \multicolumn{2}{|c|}{$\mathrm{P}=0.0257$} & \multicolumn{2}{|r|}{$\mathrm{P}<0.0001$} & \multicolumn{2}{|c|}{$\mathrm{P}<0.0001$} \\
\hline
\end{tabular}

\subsection{The prognostic values of serum vitamin $D$, ionized calcium, phosphorus and CA15.3 in breast cancer patients before surgery}

To study the prognostic values of these parameters, the Kaplan-Meyer disease-free survival (DFS) curves were constructed. Kaplan-Meyer survival curves for breast cancer patients before surgery revealed that the DFS of patients with low levels of serum 25-hydroxyvitamin D and ionized calcium (lower than their corresponding cut-off levels) were non- significantly different from those with high levels (log rank $\mathrm{P}=0.669$ and $\mathrm{P}=0.547$; respectively). Also, the DFS of patients with high serum levels of phosphorus and CA15.3 (higher than corresponding cut-off levels) showed no significant difference from those with low levels (log rank $\mathrm{p}=0.324$ and 0.747 ; respectively) as shown in table (4).

Table 4: Prognostic values of serum 25-hydroxyvitamin D, ionized calcium, phosphorus, and CA15.3 in breast cancer patients before surgery.

\begin{tabular}{|c|c|c|c|c|c|c|c|c|}
\hline \multirow{2}{*}{ Serum biomarkers } & \multirow{2}{*}{ Cut-off value } & \multirow{2}{*}{$\mathrm{N}$} & \multicolumn{2}{|c|}{ Metastasis } & \multicolumn{2}{|c|}{ Non-metastasis } & \multirow{2}{*}{$\begin{array}{l}\text { Mean } \pm \text { SD } \\
\text { (months) }\end{array}$} & \multirow{2}{*}{ P-value } \\
\hline & & & No. & $\%$ & No. & $\%$ & & \\
\hline 25- hydroxyvitamin D & $\geq 66.73(-\mathrm{ve})$ & 5 & 1 & 20 & 4 & 80 & $24 \pm 1.2$ & \\
\hline$(\mathrm{ng} / \mathrm{dl})$ & $<66.73(+\mathrm{ve})$ & 40 & 5 & 12.5 & 35 & 87.5 & $25.87 \pm 1.3$ & 0.669 \\
\hline Ionized calcium & $>4.85(-\mathrm{ve})$ & 6 & 1 & 16.7 & 5 & 83.3 & $22.33 \pm 0.9$ & \\
\hline$(\mathrm{mg} / \mathrm{dl})$ & $\leq 4.85(+\mathrm{ve})$ & 39 & 5 & 12.8 & 34 & 87.2 & $25.18 \pm 1.7$ & 0.547 \\
\hline Phosphorus & $\leq 3.65(-\mathrm{ve})$ & 28 & 5 & 17.8 & 23 & 82.2 & $24.26 \pm 2.2$ & \\
\hline$(\mathrm{mg} / \mathrm{dl})$ & $>3.65(+v e)$ & 17 & 1 & 5.9 & 16 & 94.1 & $23.35 \pm 1.1$ & 0.324 \\
\hline CA15.3 & $\leq 21.46(-\mathrm{ve})$ & 29 & 3 & 10.3 & 26 & 89.7 & $23.41 \pm 2.1$ & 0747 \\
\hline$(\mathrm{U} / \mathrm{ml})$ & $>21.46(+\mathrm{ve})$ & 16 & 3 & 18.7 & 13 & 81.3 & $25.19 \pm 1.8$ & 0.147 \\
\hline
\end{tabular}

$\mathrm{N}$ : number of cases

\section{Discussion}

In the present study, serum levels of 25- hydroxyvitamin D $(25(\mathrm{OH}) \mathrm{D})$ were significantly lower in breast cancer patients than in apparently healthy controls. Our results agreed with Engel et al. [23] and Rejnmark et al [24] and disagreed with Eliassen et al [25] and Almquist et al [14].

In the present study, serum $25(\mathrm{OH}) \mathrm{D}$ showed a significant odd's ratio $(0.0937,95 \% \mathrm{CI}=0.0311-0.2823)$ which indicated that individuals with serum levels of $25(\mathrm{OH}) \mathrm{D} \geq 66.73 \mathrm{ng} / \mathrm{dl}$ having a lower risk of getting breast cancer than those having $25(\mathrm{OH}) \mathrm{D}$ levels <66.73 ng/dl. Our results agreed with Engel et al [23] and Rejnmark et al [24]. On the other hand, our results disagreed with Eliassen et al [25] and Almquist et al [14] who found non-significant association between $25(\mathrm{OH}) \mathrm{D}$ level and breast cancer risk. 
There is ample evidence from cellular and animal studies linking 25(OH) D to breast cancer. This includes the known anticarcinogenic effects of vitamin D regarding apoptosis, cell differentiation and proliferation and growth inhibition of human mammary epithelial cells by both 1, $25(\mathrm{OH}) 2 \mathrm{D} 3$ and 25(OH) D [33]. Activated vitamin D exerts its antitumor effects via the vitamin $\mathrm{D}$ receptor to form a nuclear receptor-ligand complex which regulates the expression of target genes such as p21, p27, c-fos, and c-myc [26].

Several studies have shown that calcitriol $(1,25(\mathrm{OH}) 2 \mathrm{D} 3)$ inhibits the growth of human breast cancer cell lines [27], [28]. In ER+ cells such as MCF-7, calcitriol induces cell cycle arrest in the G0/G1 phase of the cell cycle by increasing the expression of cyclin-dependent kinase inhibitors such as p21Waf/Cip1, decreasing cyclin-dependent kinase activity and causing the dephosphorylation of the retinoblastoma protein [29]. Calcitriol and its analogs also inhibit the growth of breast cancer cells by regulating the expression of oncogenes such as c-myc and c-fos and modulating the actions of several growth factors, including epidermal growth factor (EGF), transforming growth factor $\beta$ (TGF $\beta$ ) and insulin-like growth factor-I (IGF-I) [27], [30].

Vitamin D helps to maintain breast epithelial cells in a well-differentiated status via up regulation of the glycoprotein Ecadherin [31] by $\beta$-casein production [32], or by a change in overall cell size and shape associated with changed cytoarchitecture of actin filaments and microtubules in MDA-MB-453 cells [27].

In addition to causing growth arrest and differentiation, calcitriol $(1,25(\mathrm{OH}) 2 \mathrm{D} 3)$ and its analogs induce morphological and biochemical changes associated with apoptosis in breast cancer cells such as chromatin condensation and DNA fragmentation [33]. The induction of apoptosis involves the generation of reactive oxygen species, mitochondrial disruption and the release of cytochrome C [34]. Both caspase-dependent and independent pathways are enhanced, which result in increased mitochondrial membrane damage and cytochrome c release [35]. These changes might be related to the regulation of the expression of bcl-2 family of genes by calcitriol resulting in a decrease in the relative expression of anti-apoptotic proteins such as bcl-2 and bcl-XL to pro-apoptotic proteins such as bax and bak [36].

Other mechanisms of the suppressive effects of calcitriol on invasion and metastasis include decreases in the activities of matrix metalloproteinases (MMPs), urokinase-type plasminogen activator (uPA) and tissue-type plasminogen activator and increases in the expression of PA inhibitor 1 (PAI1) and MMP inhibitor 1[30]. Calcitriol also has a potent antiangiogenic activity that might contribute to its actions to inhibit invasion and metastasis [27].

Cancer-related inflammation is characterized by the presence of inflammatory cells at the tumor site and the overexpression of inflammatory mediators such as cytokines, chemokines, prostaglandins (PGs) and reactive oxygen and nitrogen species in tumor tissue [37]. In both ER-positive and ER-negative human breast cancer cells, calcitriol downregulates the expression of cyclooxygenase-2 (COX-2), the rate-limiting enzyme catalyzing prostaglandins synthesis. Calcitriol also increases the expression of 15-hydroxyprostaglandins dehydrogenase (15-PGDH), which catalyzes the conversion of prostaglandin to biologically inactive keto-derivatives. As a result, calcitriol treatment significantly reduces both the synthesis and the biological activity of prostaglandins in breast cancer cells [38].

Calcitriol inhibits the synthesis and the biological actions of estrogens, the major stimulators of breast cancer growth, by exerting repressive effects on the expression of the gene encoding aromatase (CYP19A1), the enzyme that catalyzes estrogen synthesis from androgenic precursors. Calcitriol also down-regulates ER $\alpha$, the nuclear receptor that mediates estrogen actions. These combined actions reduce the levels of the estrogenic hormones and the receptor that mediates their signaling [39].

In the current study, no correlation was found between vitamin D and clinico-pathological data. These results agreed with Rejnmark et al [24] and disagreed with Engel et al [23] and Crew et al [26].

In the present study, on following breast cancer patients for 24 months after completing 6 cycles of chemotherapy, of the five patients who had serum vitamin $\mathrm{D} \geq 66.73 \mathrm{ng} / \mathrm{dl}$, one $(20 \%)$ had metastasis and four $(80 \%)$ were free of metastasis. Of the fourty patients who had serum level $<66.73 \mathrm{ng} / \mathrm{dl}$, five $(12.5 \%)$ had metastasis and thirty-five $(87.5 \%)$ were non-metastatic. We found no significant association between preoperative vitamin D level and diseasefree survival (DFS). Our results indicated that vitamin D cannot be used as a prognostic factor in breast cancer patients. These results agreed with Freedman et al [40] and disagreed with Tretli et al [41].

Calcium is an important intracellular messenger, involved in processes related to proliferation, apoptosis and cell signaling. The calcium-sensing-receptor (CaSR) is expressed both in normal and malignant breast cells and its expression is correlated with skeletal metastasis [15].

In the present study, serum level of ionized calcium was significantly lower in breast cancer patients than in apparently normal healthy controls. These results agreed with Sergeev [42] and disagreed with Sprague et al [43].

In the present study, serum ionized calcium showed a significant odd's ratio $(\mathrm{OR}=0.0464,95 \% \mathrm{CI}=0.015-0.141)$ which indicated that individuals with levels of $\mathrm{Ca}^{2+}>4.85 \mathrm{mg} / \mathrm{dl}$ having lower risk of getting breast cancer than individuals having levels of $\mathrm{Ca}^{2+} \leq 4.85 \mathrm{mg} / \mathrm{dl}$. These results agreed with Almiquist et al [24] and disagreed with Sprague et al [43]. Cellular $\mathrm{Ca}^{2+}$ has been strongly implicated in induction of apoptosis. It is hypothesized that a sustained increase in ionized calcium $\left[\mathrm{Ca}^{2+}\right] \mathrm{i}$, not reaching cytotoxic levels, signals the cell to enter the apoptotic pathway via activation of the $\mathrm{Ca}^{2+}$ - dependent neutral proteses, calpains, followed by activation of the $\mathrm{Ca}^{2+} /$ calpain-dependent caspase- 12 and executor caspases, thus, facilitate induction of apoptosis [44].

In the current study, no correlation was found between serum ionized calcium, and clinicopathological features. These results agreed with Martin et al [45] and disagreed with Almquist et al [15].

In the present study, on following breast cancer patients for 24 months, of the six patients who had serum ionized $\mathrm{Ca}^{2+}$ level $>4.85 \mathrm{mg} / \mathrm{dl}$, one $(16.7 \%)$ had metastasis and five $(83.3 \%)$ were free of metastasis. Of the thirty-nine patients who 
had serum ionized calcium level $\leq 4.85 \mathrm{mg} / \mathrm{dl}$, five $(12.8 \%)$ were metastatic and thirty-four were free of metastasis $(87.2 \%)$. We found no significant association between ionized calcium and DFS. Our results indicated that ionized calcium cannot be used as a prognostic factor. These results agreed with Brada el al [46] and disagreed with Kristensen et al [47] as survival was found to be inversely associated with serum ionized calcium levels.

It was found that elevated levels of phosphorus were necessary for adequate growth of some types of cancers [6], [7]. This rise in phosphorus is due to heightened requirements of protein synthesis needed during accelerated cell growth [8]. Furthermore, a high phosphate diet has been reported to promote colonic cell hyperplasia and hyperproliferation in mice, indicating a role of $\mathrm{Pi}$ in carcinogenesis [47].

Elevated Pi has been suggested to promote development of cancer via amplifying Akt (also known as protein kinase B) signaling activities and enhancing cap-dependent translation, eventually resulting in increased cell proliferation. Intracellular Pi serves as an important signalling molecule by affecting specific downstream molecules [5]. This common signaling mechanism operates through active phosphorylated Akt that stimulates cell cycle progression and other cellular events that result in a common lung cancer [5, 48]. Once activated inside the epithelial cell membrane, phosphorylated Akt facilitates a cascade of phosphate additions in the cytoplasm and nucleus that results in an increase in cap-dependent protein translation, more rapid cell cycle progression, and tumor formation [49].

Furthermore, the increase in serum phosphorus is accompanied with decrease in serum ionized calcium due to the formation of calcium-phosphate salts. Elevated serum phosphate concentration alters the extracellular Ca-phosphate equilibrium to promote formation of Ca-phosphate precipitates, which are then deposited in various body tissues [50]. In the present study, serum levels of phosphorus were significantly higher in breast cancer patients than in apparently normal controls.

In the present study, serum phosphorus showed a significant odd's ratio $(2.6801,95 \% \mathrm{CI}=1.1269-6.3742)$ which indicated that individuals having serum phosphorus levels $>3.65 \mathrm{~g} / \mathrm{dl}$ have higher risk of getting breast cancer than individuals having levels of phosphorus $<3.65 \mathrm{mg} / \mathrm{dl}$.

In the current study, a positive association was found between serum phosphorus and age and menopausal status of the patients. Because estrogen is known to enhance renal phosphorus excretion and decrease the efflux of phosphorus from bone that's why serum phosphorus increase by aging [51]. However, serum phosphorus non- significantly correlated with the other clinicopathological data.

In the present study, on following breast cancer patients for 24 months, of 17 patients who had serum level more than $3.65 \mathrm{mg} / \mathrm{dl}$, one $(5.9 \%)$ was metastatic and $16(94.1 \%)$ were non-metastatic. Of 28 patients who had serum phosphorus level less than $3.65 \mathrm{mg} / \mathrm{dl}$ five $(17.8 \%)$ had metastasis and $23(82.2 \%)$ were free of metastasis. We found no significant association between phosphorus and DFS. Our results indicated that phosphorus cannot be used as a prognostic factor. To the best of our knowledge, this is the first study evaluating the prognostic role of serum phosphorus in breast cancer. CA15.3 is the most widely used breast cancer marker. In the present study, serum level of CA15.3 was significantly higher in breast cancer patients than in normal healthy control. These results agree with Hewala et al [52] and Duffy et al [16]. In the current study, no correlation was found between serum CA15.3 and clinicopathological data. These results disagreed with Park et al [53].

In the present study, on following breast cancer patients for 24 months, of the 16 patients who had serum CA15.3 levels more than $21.46 \mathrm{U} / \mathrm{ml}, 3(18.7 \%)$ were metastatic and $13(81.3 \%)$ were non-metastatic. Of 29 the patients who had serum CA15.3 level less than $21.46 \mathrm{U} / \mathrm{ml}$, three $(10.3 \%)$ had metastasis and $26(89.7 \%)$ were free of metastasis. In this study, we found no significant association between CA15.3 and DFS. Our results indicated that CA15.3 cannot be used as a prognostic factor. Our results disagreed with Park et al [53].

The ROC curve analysis was used in the present study to compare the diagnostic value of serum vitamin $\mathrm{D}$, ionized calcium, phosphorus, and CA15.3 depending on the area under the ROC curve (AUC).The higher AUC corresponds to a better diagnostic test. Serum ionized calcium showed a significant AUC (81.7\%), ( $\mathrm{p}=0.00)$, with sensitivity (72.7\%) and specificity $(84.1 \%)$ at a cut-off value $(4.85 \mathrm{mg} / \mathrm{dl})$. Serum 25 -hydroxyvitamin D showed a significant AUC (75.3\%), $(\mathrm{p}=0.00)$, with sensitivity $(56.8 \%)$ and specificity $(88.6 \%)$ at a cut-off value $(66.73 \mathrm{ng} / \mathrm{ml})$. Serum CA15.3 showed a significant AUC $(70.1 \%),(\mathrm{p}=0.001)$, with sensitivity $(36.4 \%)$, and specificity $(88 \%)$ at cut-off value $(21.46 \mathrm{U} / \mathrm{ml})$. Serum phosphorus showed a significant AUC (62.8\%), (p=0.04), with sensitivity $(61.4 \%)$ and specificity $(62.8 \%)$ at a cut-off value $(3.65 \mathrm{mg} / \mathrm{dl})$. These result suggested that serum ionized calcium and vitamin $\mathrm{D}(25(\mathrm{OH}) \mathrm{D})$ are superior to CA15.3 and phosphorus for diagnosis of breast cancer patients. To the best of our knowledge, this is the first study in Egypt that compares the diagnostic value of serum ionized calcium, vitamin D $(25(\mathrm{OH}) \mathrm{D})$ and phosphorus with those of serum CA15.3 with determination of the precise cut- off value, sensitivity and specificity of each serum marker in breast cancer patients.

\section{Conclusion}

From this study, it could be concluded that serum 25- hydroxyvitamin D, ionized calcium, phosphorus and CA15.3 can be used for diagnosis of breast cancer patients of clinical stages II and III with serum ionized calcium and 25hydroxyvitamin D were superior to CA15.3 and phosphorus. Serum 25(OH) D and ionized calcium had a protective role while serum phosphorus is risky in breast cancer of clinical stages II and III. None of the assayed biomarkers has a 
prognostic role in breast cancer. The contradiction between our results and the results of the other studies can be explained by the small sample size of patients and controls and short follow-up period used in our study.

\section{Conflict of interest}

No conflict of interest is declared.

\section{References}

[1] Azaiza F, Cohen M. Health beliefs and rates of breast cancer screening among Arab women. J Women's Health 2006; 15:520-30. http://dx.doi.org/10.1089/jwh.2006.15.520.

[2] Shoma AM, Mohamed MH, NoumanN, MohamedA, Ibrahim MI, Tobar SS, et al. Body image disturbance and surgical decision making in Egyptian postmenopausal breast cancer patients. World J Surg Oncol 2009; 7:66-77. http://dx.doi.org/10.1186/1477-7819-7-66.

[3] Randi G, Edefonti V, Ferraroni M, La Vecchia C, Decarli A. Dietary patterns and the risk of colorectal cancer and adenomas. Nutr Rev 2010; 68:389-408. http://dx.doi.org/10.1111/j.1753-4887.2010.00299.x.

[4] Conrads KA, Yi M, Simpson KA, Lucas DA, Camalier CE, Yu LR, et al. A combined proteome and microarray investigation of inorganic phosphate-induced pre-osteoblast cells. Mol. cellul proteomics: MCP 2005; 4:1284-96.

[5] Chang SH, Yu KN, Lee YS, An GH, Beck GR Jr, Colburn NH, et al. Elevated inorganic phosphate stimulates Akt-ERK1/2-Mnk1 signaling in human lung cells. Am J Respirat Cell Mol Biol 2006; 35:528- 39? http://dx.doi.org/10.1165/rcmb.2005-0477OC.

[6] Camalier CE, Young MR, Bobe G, Perella CM, Colburn NH, Beck GR Jr. Elevated phosphate activates N-ras and promotes cell transformation and skin tumorigenesis. Cancer Prev Res (Phila) 2010; 3:359-70. http://dx.doi.org/10.1158/1940-6207.CAPR-09-0068.

[7] Jin H, Chang SH, Xu CX, Shin JY, Chung YS, Park SJ, et al. High dietary inorganic phosphate affects lung through altering protein translation, cell cycle, and angiogenesis in developing mice. Toxicol sciences: an official journal of the Society of Toxicology 2007; 100:21523. http://dx.doi.org/10.1093/toxsci/kfm202.

[8] Holick MF. Too little vitamin D in premenopausal women: why should we care? Am J Clin Nutr 2002; 76:3-4?

[9] Hansen CM, Binderup L, Hamberg KJ, Carlberg C. Vitamin D and cancer: effects of 1,25(OH)2D3 and its analogs on growth control and tumorigenesis. Front Biosci 2001; 6: 820-48. http://dx.doi.org/10.2741/Hansen.

[10] Grant WB. An estimate of premature cancer mortality in the US because of inadequate doses of solar ultraviolet- B radiation. Cancer 2002; 94:1867-75. http://dx.doi.org/10.1002/cncr.10427.

[11] Garland F, Garland C, Gorham E, Young J Jr. Geographic variation in breast cancer mortality in the United States: a hypothesis involving exposure to solar radiation. Prev Med 1990; 19: 614-22. http://dx.doi.org/10.1016/0091-7435(90)90058-R.

[12] Nesby-O'Dell S, Scanlon KS, Cogswell ME, Gillespie C, Hollis B W, Looker AC, et al. Hypovitaminosis D prevalence and determinants among African American and white women of reproductive age: third National Health and Nutrition Examination Survey, 1988-1994. Am J Clin Nutr 2002; 76:187-92?

[13] Wang Q, Lee D, Sysounthone V, Chandraratna RA, Christakos S, Korah R, et al. 1, 25-dihydroxyvitamin D3 and retinoic acid analogues induce differentiation in breast cancer cells with function- and cell-specific additive effects. Breast Cancer Res Treat 2001; 67: 157-68. http://dx.doi.org/10.1023/A:1010643323268.

[14] Almquist M, Manjer J, Bondeson L, Bondeson A. Serum calcium and breast cancer risk: results from a prospective cohort study of 7,847 women. Cancer Causes Control 2007; 18: 595-602. http://dx.doi.org/10.1007/s10552-007-9001-0.

[15] Almquist M, Bondeson A, Bondeson L, Malm J, Manjer J. Serum levels of vitamin D, PTH and calcium and breast cancer risk-a prospective nested case-control study. Int J Cancer 2010; 127: 2159-68. http://dx.doi.org/10.1002/ijc.25215.

[16] Duffy MJ. CA 15-3 and related mucins as circulating markers in breast cancer. Ann Clin Biochem 1999; 36: 579-86. http://dx.doi.org/10.1177/000456329903600503.

[17] KeyhaniM, Nasizadeh S, Dehghannejad A. Serum CA 15-3 measurment in breast cancer patients before and after mastectomy. Arch Iranian Med 2005; 8: 263-6.

[18] Haskell CM, Lowitz BB, Casciato AD. Breast cancer. In: Casciato AD and Lowitz BB (Eds). Manual of clinical oncology 2nd ed. Boston, Toronto: Little and Brown Company; 1985: pp 150-65.

[19] Rintoul RF. Operations on the breast. In: Fagquharson's textbook of operative surgery. 7th ed Rintoul RF (ed) Churchill-Livingstone Inc. 1986: $\mathrm{p} 279$

[20] AbeloffMD, Lichter AS, Niederhuber JE, pierce LJ, Aziz DC. Breast In: Abeloff MD, Armitage JO, Lichter AS, NiederhuberJE; eds. Clinical oncology. 4th ed. Churchil living stone inc. (pub). Chapter 73, 1995; pp1617-714.

[21] Meyerhaff ME, Opdycke WN. Ion-selctive electrodes. Adv clinic chem1986; 25:1-41. http://dx.doi.org/10.1016/S0065-2423(08)60123-7.

[22] Altman DG, Gardner M. Diagnostic tests. In: Altman DG, Machin D, Trevor NB, (eds). Statistics with confidence 2nd ed. BMJ Books; 2000 : pp 105-19.

[23] Engel P, Fagherazzi G, Boutten A, Dupré T, Mesrine S, Boutron-Ruault MC, et al. Serum 25(OH) vitamin D and risk of breast cancer: a nested case-control study from the French E3N cohort. Cancer Epidemiol Biomarkers Prev 2010; 19:2341-50. http://dx.doi.org/10.1158/10559965.EPI-10-0264.

[24] Rejnmark L, Tietze A, Vestergaard P, Buhl L, Lehbrink M, Heickendorff L, et al. Reduced prediagnostic 25-hydroxyvitamin D levels in women with breast cancer: a nested case-control study. Cancer Epidemiol Biomarkers Prev 2009; 18:2655-60. http://dx.doi.org/10.1158/10559965.EPI-09-0531.

[25] Eliassen AH, Spiegelman D, Hollis BW, Horst RL, Willett WC, Hankinson SE. Plasma 25-hydroxyvitamin D and risk of breast cancer in the Nurses' Health Study II. Breast Cancer Res 2011; 13:1-7. http://dx.doi.org/10.1186/bcr2880.

[26] Crew KD, Gammon MD, Steck SE, Hershman DL, Cremers S, Dworakowski E, et al. Association between plasma 25 hydroxyvitamin D and breast cancer risk. Cancer Prev Res 2009; 2:598-604. http://dx.doi.org/10.1158/1940-6207.CAPR-08-0138.

[27] Colston KW, Hansen CM. Mechanisms implicated in the growth-regulatory effects of vitamin D in breast cancer. Endocr Relat Cancer 2001; 9:45-59. http://dx.doi.org/10.1677/erc.0.0090045.

[28] Pendas-Franco N, Gonzalez-Sancho JM, Suarez Y, Aguilera O, Steinmeyer A, Gamallo C, et al. Vitamin D regulates the phenotype of human breast cancer cells. Differentiation 2007; 75:193-207. http://dx.doi.org/10.1111/j.1432-0436.2006.00131.x.

[29] Roy PG, Thompson AM. Cyclin D1 and breast cancer. The Breast 2006; 15: 718-27. http://dx.doi.org/10.1016/j.breast.2006.02.005.

[30] Wang Q, Lee D, Sysounthone V, Chandraratna RA, Christakos S, KorahR,et al. 1,25-dihydroxyvitamin D3 and retinoic acid analogues induce differentiation in breast cancer cells with function- and cell-specific additive effects. Breast Cancer Res Treat 2001; 67: 157-68. http://dx.doi.org/10.1023/A:1010643323268.

[31] Berx G, Van Roy F. The E-cadherin/catenin complex: an important gatekeeper in breast cancer tumorigenesis and malignant progression. Breast Cancer Res 2001; 3:289-93. http://dx.doi.org/10.1186/bcr309. 
[32] Rocker D, Ravid A, Liberman UA, et al. () 1, 25- Dihydroxyvitamin D3 potentiates the cytotoxic effect of TNF on human breast cancer cells. Mol Cell Endocrinol 1994; 106:157-62. http://dx.doi.org/10.1016/0303-7207(94)90198-8.

[33] Brosseau CM, Pirianov G, Colston KW. Involvement of stress activated protein kinases (JNK and p38) in 1, 25 dihydroxyvitaminD3-induced breast cell death. Steroids 2010; 75: 1082-8. http://dx.doi.org/10.1016/j.steroids.2010.07.007.

[34] Narvaez CJ, Welsh J. Role of mitochondria and caspases in vitamin D-mediated Apoptosis of MCF-7 breast cancer cells. J Biol Chem 2001; 276:9101-7. http://dx.doi.org/10.1074/jbc.M006876200.

[35] Wactawski-Wende J, Kotchen JM, Anderson GL, Assaf AR, Brunner RL, O'Sullivan MJ, et al. Calcium plus vitamin D supplementation and the risk of colorectal cancer. N Engl J Med 2006; 354: 684-96. http://dx.doi.org/10.1056/NEJMoa055222.

[36] Narvaez CJ, ZinserGM, Welsh JE. Functions of 1, 25-dihydroxyvitamin D3 in mammary gland: from normal development to breast cancer. Steroids 2001; 66: 301-8. http://dx.doi.org/10.1016/S0039-128X(00)00202-6.

[37] Mantovani A, Pierotti MA. Cancer and inflammation: a compel relationship. Cancer Lett 2008; 267:180-1. http://dx.doi.org/10.1016/j.canlet.2008.05.003.

[38] Krishnan AV, Swami S, Peng L, Wang J, Moreno J, Feldman D. Tissue-selective regulation of aromatase expression by calcitriol: implications for breast cancer therapy. Endocrinol 2010; 15:32-42. http://dx.doi.org/10.1210/en.2009-0855.

[39] Chen S. Aromatase and breast cancer. Front Biosci 1998; 3:922-33.

[40] Freedman DM, Looker AC, Chang SC, Graubard BI. Prospective study of serum vitamin D and cancer mortality in the United States. J Natl Cancer Inst 2007; 99:1594 - 602. http://dx.doi.org/10.1093/jnci/djm204.

[41] Tretli S, Schwartz G, Torjesen PA, Robsahm TE. Serum levels of 25-hydroxyvitamin D and survival in Norwegian patients with cancer of breast, colon, lung and lymphoma:a population-based study. Cancer Causes Control 2012; 23:363-70. http://dx.doi.org/10.1007/s10552-0119885-6.

[42] Sergeev IN. Vitamin D and cellular $\mathrm{Ca}^{2+}$ signaling in breast cancer. Anticancer Res 2012; 32: 299-302.

[43] Sprague BL, Skinner HG, Tentham-Dietz A, Lee KE, Klein BE, Klein R. Serum calcium and breast cancer risk in a prospective cohort study. Ann Epidemiol 2010; 20:82-5. http://dx.doi.org/10.1016/j.annepidem.2009.09.001.

[44] Sergeev IN. Calcium signaling in cancer and vitamin D. J Steroid Biochem Mol Biol 2005; 9: 145-51. http://dx.doi.org/10.1016/j.jsbmb.2005.06.007.

[45] Martin E, Miller M, Krebsbach L, Beal J, Schwartz G, Sahmoun A. Serum calcium levels are elevated among women with untreated postmenopausal breast cancer. Cancer Causes Control 2009; 21:251-7. http://dx.doi.org/10.1007/s10552-009-9456-2

[46] Brada M, Rowley M, Grant DJ, Ashley S, Powels TJ. Hypercalcemia in patients with disseminated breast cancer. Acta Oncologica 1990; 29:577-80. http://dx.doi.org/10.3109/02841869009090054

[47] Newmark HL, Lipkin M, Maheshwari N. Colonic hyperplasia and hyperproliferation induced by a nutritional stress diet with four components of Western-style diet. J National Cancer Institute 1990; 82:491-6. http://dx.doi.org/10.1093/jnci/82.6.491.

[48] Hers I, Vincent E, Tavare J.M. Akt signaling in health and disease. Cell Signal 2011; 23: 1515-27. http://dx.doi.org/10.1016/j.cellsig.2011.05.004.

[49] Xu CX, Jin H, Lim HT, Kim JE, Shin JY, Lee ES, et al. High dietary inorganic phosphate enhances cap-dependent protein translation, cellcycle progression, and angiogenesis in the livers of young mice. Am J Physiol Gastrointest Liver Physiol. 2000; 295 : 654-63. http://dx.doi.org/10.1152/ajpgi.90213.2008.

[50] Methnney NM. Calcium imbalances. In: Fluid and electrolyte balance 5th ed. Jones \& Bartlett Learning LLC. 2012: pp 91-109.

[51] McKane WR, Khosla S, Burritt MF, Kao PC, Wilson DM, Ory SJ, et al. Mechanism of renal calcium conservation with estrogen replacement therapy in women in early postmenopause. J Clin Endocrinol Metab 1995; 80: 3458-64

[52] Hewala T, Abd El-Moneim N, Ebeid S, Anwar M. The clinical significance of serum soluble Fas and p53 in breast cancer patients: comparison with serum CA15.3. Path Oncol Res 2012; 18: 841-8. http://dx.doi.org/10.1007/s12253-012-9512-1.

[53] Park BW, OH JW, Park SH, Kim KS, Kim JH, et al. Preoperative CA 15-3 and CEA serum levels as predictor for breast cancer outcomes. Annals of Oncol 2008; 19: 675-81. http://dx.doi.org/10.1093/annonc/mdm538. 